\title{
例会要 旨
}

《第170回例会 (特別例会)》(新潟地理学会之共催) 1987年 6 月13日（土）

於 公立学校共済組合新潟会館 福島潟周辺の開発一一明治以降を中心に一-

島 吾郎 (巻高校)

北越雪譜に越の湖として記載された福島潟は新潟 目の北部にあり，北を10列にも及ぶ砂堆列，西を阿 賀野川，東と南を第 3 紀から洪積世にかけて形成さ れたケルンバット状の陣ケ峯丘陵によって閉塞され た老年期に相当する富栄養湖である。本発表は潟と 「㴓端」に生きる農漁民和よび周辺住民との関係を 社会経済状勢・自然環境の変化を通して考察したる のである。すなわち住民にとっての潟の存在意義を 時代を区切って明らかにしようとしたものである。

第 I 期 江戸時代 新発田藩と町人資本による開 発が行われた時期である。1730年（享保15年）に実 現した阿賀野川の松ヶ崎切り落としによる潟周辺の 干陸化によって新田開発が進行した。享保年間から 天保年間にかけて新田が形成され，頸城郡の山本丈 右衛門・水原の市島家・新発田藩が開発の主体之な った。この期は潟西岸の自然堤防とデルタの部分が 中心に開かれ，斎藤晃吉氏が「北陸型輪中」と指摘 した「古囲」「新囲」といった囲い地が造成された。 自然堤防や砂堆上に多くの新田村が成立した。

第II期 明治期から昭和 20 年 湖岸砂丘上飞居を 移した千町歩地主市島家による潟面支配と開発が行 われた時期である。農業では地主一羑配人一小作制 代一小作人，漁業では地主一世話人または見迴人一 漁民といった支配と被支配の構図が確立された。市 島家は福島潟排水機の設置・唯一の排水河川である 新井郷川に甜ける水害予防組合の設立・魚族繁殖組 合（後の福島潟水産組合）の結成を通して米と水産 物の運上の安定と増産を試みた。潟端農漁民は地主 制といら制約下に扔いて秝場の開田をはごめとする 水田所有を強く希求していた。この時期開田の問題 となったのが潟の東岸から南岸にかけて発達する丘 陵からいっきに流入する中小河川の上流既耕地と河
口開墾地間の治水をめぐる対立であった。河口部で の堤防構築と開田が上流耕地の 湛水につながった （市島家の 地主構造のうち 福島潟ノ一部開墾二付御 伺書)。また同様に，「新々团」「山倉团」「市島团」 が造成されたが，囲い地内の地租の延期願いの状況 から干拓地の土地条件の劣悪さを知ることができる

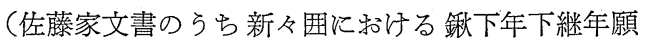
之件聞届く)。この期には近世に成立した新田村の 枝村が潟の人工堤防上に列村状に形成された。

第正期 昭和 20 年から昭和 45 年 潟の所有権が市 島家から国に移管され，戦後の食糧増産を目的に本 格的に全面干拓が企画されたと同時に，はじめて潟 端農漁民の手に干拓地が渡った時期である。昭和 20 年代には潟に付属した黒山潟・内沼潟がいち大字の 地元農民と戦後引揚者によってそれぞれ干拓された。 農地改革期には農地委員会之地元の葛嗝町 (現豊栄 市）長を中心に 1 市 1 町 2 村の首長が結束し干拓期 成同盟会が創設され，県と国への㗢きか子が実り， 昭和31年には潟の所有権が市島家から国に移った。 昭和36年には新井郷川河口に当時東洋一の規模を誇 る排水機が完成し潟の干拓条件が整ったかにみ兄た。 県が進めた百万 $\mathrm{t}$ 米作り運動の状況下で干拓計画が 進むが，昭和 $41 ・ 42$ 年に発生した羽越水害の教訓か ら潟の遊水池としての役割が再認識された。水害の 背景には農業構造改善事業による周辺耕地汸护る 大型圃場整備事業の進行と，潟へ流入する中小河川 の直流化打よび護岸の強化，さらにはかつて行われ ていた潟の泥土を水田に投入する, 客土作業の消隇 による湖床の上昇が挙げられる。また昭和 50 年に始 まった陣ケ峯丘陵のゴルフ場建設る再重なる水害の 要因となった。さらに昭和 44 年暮れ，米の生産調整 通知が届けられ，干拓地の米作りとしての環境は土 地条件の変化と農業政策の転換によって悪化した。 この結果潟端農民の営農意欲はやや弱められ，干拓 地も 167 ha と決定縮小された。結局, 潟の半分は 調整地として残されることになった。

第 $\mathrm{N}$ 期 昭和 46 年から現在 この時期には米作り 
への諸条件の悪化と, 近接する新潟市の都市化の間 接的な影響が出はじめた。また昭和50年代後半から 起った潟の風致地区としての整備と観光地化計画が 起ってきた。昭和46年には干陸式が行われ, 自立経 営農家の育成を前提に潟端農家 227 戸に耕地が配分 された。乙かし兼業化の促進と干拓地の土地改良費 の高負担がかさんだことが大きな要因となり, 新潟 市内の市街化区域汇近接する農家や新潟東工業港開 発計画区域内の買収農地の代替地として地価の安い 干拓地が譲渡されている。いっぽら豊栄市の行政と 市民グループは「地域叔こし」の対象に潟を取りあ げている。水禽公園化計画を核に潟を市民の共有財 産,すなわち豊栄市のアイデンティティとして開発 する計画である。観光資源としてはわが国初の鳥類 一級観測所・ひしくいの飛来・水郷景観が挙げられ ている。

戦後福島潟は地主から解放され潟端農民の耕地と して生まれ変わったが, 潟の存在は農民の生産の場 から直接生産にたずさわらない市民の精神的なたは 観光開発の対象として変化している。しかし干拓地 は蒲原豰倉地帯の一角を占めていることから, 潟と その周辺の自然環境や生態系を充分考慮した開発と 既耕地の保護が今後の大きな課題となっている。

(スライド使用)

\section{小売業・サービス業のチェーン展開過程}

\section{志村喬（新潟県立川西高校）}

小売業・サービス業に和いては, 需要が空間的に 分散して, 施設の利用にあたっては個人の移動とい ら負担が一般的に必要とされる。したがって，これ ら業態の企業が, 企業規模拡大を図る場合, 単一地 点での店舗規模拡大には限界があり, 複数の店舗を 空間的に分散立地させなければならない。この分類 立地は，小売業の技術革新であるチェーンストア技 術により実現された。特に，スーパーマーケットチ ェーンは，この技術の利用により著しい企業拡大を 行った。また, その店舗展開は小売業の地域構造に 大きな影響を与兄ている。そこで, 本研究では, こ のチェーン展開過程について企業行動という視点か ら検討してみた。
この過程の分析方法については, 空間的拡散研究 の中にその糸ロを見つけることが出来る。一つは， チェーンストア技術を技術革新ととらえて「地域に 新しい業態が普及する」といら視点から分析する方 法である。この例としては, Cohen (1972) の合衆 国に和けるショッピングセンター展開の分析, 成 （1978）の韓国に括けるスーパーマーケット展開に 関する分析がある。ここでは，普及を説明する様々 な要因の存在や, 人口規模 - 都市の経済的特性と展 開との関係及び企業行動研究の必要性が指摘された。 一方では，「企業が 新しい施設を配置してゆく」 といら企業側の視点からの分析もある。この例とし ては, Brown 他 (1979, 1981) の研究があげられ る。これは, 合衆国に和ける郊外レストランチェー ンの展開を事例として, その空間的展開過程を, 空 間的拡散研究の手法を応用して説明したものである。 Brown 他は先ずチェーン店の立地位置と立地時期 を主に規定する要因は，(1)市場のポテンシャル (2) 本部一店舗間の移動・配送等に要する費用（距離に 換置される）(3)資本力，の3つだとし，その要因 の関係を, 市場及び距離に関する変数を説明变数・ 店舗の立地年次を被説明变数とした重回帰分析によ り明らかにした。そこでは, 踊例企業に資本力が充 分ではなかっで展開期間の前期では, 費用最小化戦 略が採用されたため店舗の空間的展開は距離に大き く制約されたこと, 他方, 資本力がついた後期では, 収入最大化戦略が採用されたために店舗の展開は市 場（収入）に適応した立地をとり距離の制約は減じ たこと,が結論として導き出されている。この分析 万法は, (1)企業内部の状況からチェーン展開を説明, (2)時間をとり入れて店舗立地を説明，乙た点から評 価できる。そこで, この方法を, 茨城県のスーパー 企業に適用してチェーン展開過程を分析してみた。

対象とした事例企業は，土浦市に本部を置く県内 最大手の企業である。1961年に初の店舗を開設して から82年に至るまで, 県内34市町村に49店舗, 県外 を含めると62店舗の展開を計っており，82年の売上 高ランキング（スーパー）は全国18位である。この 企業の店舗立地選定過程では, トップの決定から次 第に空間的範囲が狭められてゆき，それに対応して 
考慮される立地因子・条件が異なってゆくことが確 認された。また，展開の空間的範囲を制約するもの として, 中央の配送センターから商品輸送すること から生ずる時間的・費用的制約（商品供給の制約） と本部一支店間の職員の移動・連絡から生ずる制約 （店舗管理の制約）が 確認された。この 2 制約は, 費用因子として作用するものであるが，本部からの 距離という数值に置換することが出来る。

分析では, 市町村を単位地区として次のように行 った。説明変数としては, 市場規模を示すものとし $\tau$, 人口・人口増加率 - 飲食料品小売業年間販売額 和よびその増加率・第 3 次産業就業者比率を, 費用 を示するのとして, 本部からの距離および競合チェ ーン企業本部からの距離を設定した。そして，店埔 を立地させた市町村の性格を明らかにするために立 地市町村 - 非立地市町村の 2 群判別分析を, 店舗開 設年次を規定する要因を明らかにするために開設年 次を被説明变数にした重回帰分析を，実施した。そ の結果，開設年次に関しては，本部に近く，人口が 多い市町村皃ど早く店舗が開設されている。また， 判別分析では, 県南部地域で人口の多い市町村に開 設されたことが明らかにされた。さらに, 事例企業 の資本状況及び事業計画を検討した場合，1976年以 前と77年以後では相違があるために，この時期を境 に前・後期と区分し, 別々に判別分析をした。その 結果, 前期は本部に近く・人口増加率の低い所に開 設させたのに対し, 後期は人口が多く・人口増加率 の高い所に開設させたことが示された。この結果は， 前期は費用に制約された施設配置を, 後期は費用の 制約が減少し収入に対応した施設配置を行ったこと を意味するもの，即ち Brown の説明様式に整合す る結果と解䣋できる。今後は, 業態の多様化や分析 単位地区の問題の解決をはかり, 立地論之の関係を 明らかにする必要があるが，操作的モデルによる検 詩がそのための一つの研究方向と思われる。

\section{胆沢扇状地における近世散居集落の展開——屋敷 地の系統を中心に-}

\author{
岡村 光展 (新潟大学)
}

胆沢扇状地は複雑な地形・地質から成るため, 分
布する散居集落の成立起源も, 新旧多彩である。角 塚古墳を象徵される如く, 一部の低位段丘面の開発 が，古代〜中世にまで遡るものもあるが，中・高位 段丘面のように, 戦後の開拓を待って, 居住地化し たところもある。

主要部分が低位段丘面に位置する胆沢町の旧若柳 村地区に沶いても，近世以前に遡る散居集落がある。 近世に打ける散居集落の展開を知る手がかりとして は, 寛永 12 年検地帳, 安永年間風土記に記された屋 敷名と代数百姓書上, 明治初期の各戸の世帯主の姓 名, 過去帳, 等があげられる。これらをるとに，か なりの程度系統化できる。

明治初期の名前は, 近世の名請人名を継承してい るのが一般であるから, 過去帳上の類似の名前を辿 ることによって，順次古い名請人へ遡及することが できる。この際, 安永風土記に記された代数百姓書 上は，最も基礎的資料である。

系統は, 旧若柳村内でも, 地区による相違が見ら れる。たと觉ば，扇頂部に位置している尿前〜市野 々地区では，飢饉その他で系の絶えたものが多い中 にあって, 本家筋が点在している。これに対し, 左 岸の鹿合地区に拈いてば，古い系統が迻れるるのが 多い。ここでは, 迎市野及, 上鹿合, 中鹿合, 下鹿 合の各地区に, $\mathrm{S}$ 系, I 系, $\mathrm{K}$ 系, $\mathrm{A}$ 系, T系が展 開しているが，代数百姓書上や過去帳の分析から， 各系の総本家や初期の分家は, 寛永検地帳の名請人 に結びつく。これらの総本家を核に, 現在は希薄化 したとは言え，本・分家の紐帯に基づく同族集団 「マケ(マキ)」関係の存在が認められる。また, 現 在は地区の鎮守化しているが，大抵の総本家は鎮守 を所有し, 別当の任に当っている。何らかの形で, 中世の在家・役屋体制を継承したものと推定される。

広範囲に散居集落が展開している低位段丘面上に おいても, 部分的には寛永検地帳の名請人にまで巡 れるものがある。本・分家の位置関係を, 上述の鹿 合地区と比較すれぼ，後者の方が，古い分家につい てもより錯綜している。しかし, 後者でも, 総本家 による鎮守の祭祀や，希薄化したとは言え，マキの 存在が認められる。

寛永検地帳名請人の持高については，お和むね 1 
町〜 2 町であるが， 3 町以上の名請人も少数存在す る。一部の大規模名請人に 関して, 保有地の地字 （長宗我部検地のホノ木に相当）の中に,「○○作」 の記載がみられ，中世的土地保有関係を示すものと 考光られる。これらの少数の大持高名請人は, 屋敷 名から推定すれば，市野々〜鹿合地区にあり，これ らの地区では, 土地保有上も古い形態が近世に近付 くまで残存していたものと考光られる。これに対し て，低位段丘上に括いては，概して $1 \sim 2$ 町規模の ものが多い。また, 寛永検地名請人持高の内の, 畑 の割合も, 前者の方が高く, 今日の景観とはかなり 異ったものであった。

な拉，寛永検地帳仁された屋敷名を可能な限り (約60７0\%), 現在地に比定することはできる。従 って, 土地保有や同族集団の存在に执いて, 地区に よる若干の相違を示しつつも, 散居集落そのものは 近世初頭には，広範囲に展開していたことがわかる。

\section{生態史的方法の諸問題}

川喜田二郎 (中部大学)

今世紀初のセンプルやハンチントンらの仕事が 「環境決定論」として攻撃されたせいか，人類の生 活をその環境との関わりのままに捉えることまでも， 地理学ではあたかるタブーとなった傾きがありはし ないか。とこで環境論への掘り下げは, 地理学より むしろ周辺諸科学, 例壳ば生態学の方が深めた感が ある。1970年初頃から世界的に環境問題の危機が俄 かに現われたとき, 残念ながら地理学は積極的にそ れをリードし得なかったようである。

しかし生物学や社会学から深められた生態学的接 近には，な和歴史性の取りこみが弱く，これが特に 人類を重視した場合の弱点となっている。これにあ き足らず，乙かも昔の「地歷」的接近以上のものを 目指乞うとして，最近「生態史的」と形容したい研 究の胎動が感じられる。タイのチャオプラヤ川デル タを扱った高谷好一や「定住革命」を扱った考古学 者西田正規らの一連の論文にそれを感ずる。

より地理学的な課題としてこれを翻案すれば，自 然対人間という捉方方でなく, 人間をも重要な自然 の一環と見なした自然地理区設定の試みがもっとあ
ってもよい。例えば人間を見据光た自然地理区とし て, 東北アジアの永久凍土層地域を把握してはぞう か。私はかつて温量指数というものを創案し, その 35度線の南北で重要な自然地理区分の行われるべき ことを論じた。同様に，その85度線が少くもユーラ シア大陸で重要な文化生態学的区分に役立つことを 示唆した。それはこれが二毛作の北限であり，その ため都市を生みだす社会的余剩や農民の定着性の増 大に拘わり, 前近代的文明を早期から成熟させるこ とに関わったからである。乙かしそれは環境決定論 風に扱われるべきでなく, 生態史的に扱らべき課題 である。

生態史的に扱う場合，まず大切なのは対象を個々 の現象の羅列としてだけ捉觉るのでなく，「生態史 的パターン」として認知することが大切である。例 壳ば私は充分成熟したアジアの前近代的文明として， 中国・ヒンズー・イスラム・チベットの 4 種をとり だした。これらは文化パターンとして捉光得るだけ でなくまたそれと整合する気候帯のパターンとし ても捉光得る。更にその文化パターンを更に詳しく 検討すると，技術・経済から社会組織・価值観まで を，文化の統合的パターンの各側面として取りだす ことができる。

例えばこのような生態史的パターンの理解にとっ て，大多数の住民が関わる生業パターンは甚だ重要 である。にも拘わらず，今な持生業パターンの設定 は適切でない。西欧やチベットのそれは「農耕か, 牧畜か」なのではなく，農牧的 agropastoral とし て捉えるべきである。日本民族のそれは「稲作民族」 として捉觉るべきでなく，「水界稲作民」的パター ンとして捉光るべきだろう。今までの誤りの根元は， 生業の実態から浮いて, 狩猟・採集・漁趽・農耕・ 牧畜, あるいは稲作・畑作といった既成概念用語に ふり回されそそれで実態を無理に截断しょうとした 点にある。

生態史的パターンは歷史的に成熟する。だからそ れを単に文化史的にではなく, 生態史的に究明する 姿勢が必要である。このようなテーマとして, 例光 ば日本の集落に「山住み型」と「谷住み型」のある ことを，かつて私は提言した。 
更に，これらの生態史的パターンは，人びとの移 住と異環境に適応する創造的努力の中で変容する。 日本の火山山麓のクロボク土壤地帯の開拓民生活の 中に，こういった問題の興味ある事例を指摘できる。 I. Bowman のパイオニア・フリンジの研究なども, こらいう視角の実りある一例である。

生態史的パターンの持つ意味や，その変化のダイ ナミックスを探る上で，住民の声の研究は，すこぶ る鬽力ある課題の一例である。私とその仲間は，日 本の北上川流域の十数カ市町村と, ネパール山地の 数カ村についてそれを行なったことがある。前者の 例では，各市町村やその各集落で, ブレーンストー ミング的討論で素材を出してもらい，それをK J 法 で組み立て，更に場合によっては住民に評価しても らった。後者の例では, 快端の懇談を積みあげた。

こうして得られた結果は, 次の諸点で質問紙法に よる分析などとは全く異ったものとなる。

まず，住民の声がよく集約でき，構造的に捉兄ら れ, 重点の所在もよく判る。それは全く地域の生態 史的現実を反映している。それは地域ごとに独自で 個性的なるのである。それはその独自な地域ニーズ の凝集したものである。従ってまた，地域社会づく りの起爆力になり得る。このようにして, 生態史的 方法によって，それぞれの地域は，その地域の独自 なポテンシャルに目覚め, 独自な創造の道を歩及始 めることができる。ネパール山村に対する私たちの 技術協力は，それを充分に裏がきした。

\section{研究部会要旨}

《第11回 地理思想研究部会》

1987年 7 月11日（土）

於 日本イタリア京都会館

地理学史研究における伝記・書誌学的手法につい $\tau$

\section{源昌久（淑徳大学）}

地理学史研究のアプローチの方法・手法は, 制度 的観点からのアカデミック学派形成過程の解明, ま た，社会学的視点からの接近など，様々なものが考 えられる。これらのアプローチを活用した優れた研 究成果が多数, 発表されている。今回, 研究部会で
は, 手法の一つとして, 伝記・書誌学的アプローチ について, その内容, 地理学史研究への応用例をと りあげた。

伝記・書誌（学）という語は, Bio-bibliography (英), Biobibliographie, Bibliobiographie (独) の 翻訳である。図書館学の分野では, 伝記付（き）書 誌, 個人著述目録, 人物書誌事典, 地理学史の分野 では，書誌（学）的・伝記的などいくつかの訳語が 見受けられる。乙かし，私は，伝記・書誌あるいは 伝記・書誌学々訳出してみたい。伝記・書誌 (学) の内容は，人物書誌（個人書誌の集まり）あるいは, 伝記事典, 人名辞（事）典汇記載されている人物さ 内容索引を示す場合もある。ここでは，特定個人な いしは複数の人物の著作・研究文献のリスト(書誌) と，伝記（履歴）に関係する情報が共に記述されて いるものを意味する。

地理学史研究に和ける伝記・書誌学的アプローチ とは，地理学者あるいは地理学史上，活躍した人物 の生涯の調査と, 書誌 (著作目録拉よび研究文献目 録）の作成を基礎に，その人物の地理（学）思想を 明らかにしていくことである。

この手法の特徴の内, 重要な二つの点についての べて扢こう。第一に, 人物調査の際, 必ず, 戸籍, 遺族，墓所を探索することをまず行う。な和，この ような調查方法は, 日本の伝統的書誌学である考証 学派, 狩谷棭斎, 淽江抽斎, 森 枳園の系統に护け る研究にもみられることを付記して护く。第二に， 書誌作成の面に怙いては, 科学的な厳密な方法によ っている。従来, 地理学史のみならず, 社会科学分 野に打ける書誌作成をみてみると，ライブラリアン による書誌作成は, 主題への関心レベルが低く, 研 究水準を反映していない。一方, 主題研究者による ものは，書誌学的な厳密な方法によらず，自己流で 作成されているものが多く, 別の研究者がそれを利 用する時, 困難を生じている。このような状況で, 主題への理解と書誌学的手法を統合することに成功 すれば, 完成した書誌は, 現在の研究水準を押し上 げ，新しい研究水準への橋渡しの役目を果すである ら。

前述のような伝記・書誌学的手法を地理学史研究 
へ応用した事例の一つとして，Geographers：biobibliographical studies 1977一がある。本誌への掲載 項目 (Format) として, 次の事項が決められてい る。

A. Text in three sections:

1. Education, life and work

2. Scientific ideas and geographical thought

3. Influence and spread ideas

B. Bibliography and sources

C. Chronological table

また，この手法の一つの系譜として，Anne Buttimerにより提唱された Autobiographically-based approach が考壳られる。

\section{《第20回 経済・都市地理研究部会》}

1987年 7 月11日（土）

於 関西大学大学院会議室

\section{野尻亘・石川雄一論文討論会}

野尻亘 :「近年に和ける 石油製品輸送手段の 選択利 用の変化一一第一次石油ショック以降の石油需給 の変化と内航海運の動向に関連して一」」経済地 理学年報, 33-1， 1987.

石川雄一：「公共交通としての地下鉄利用からみた 大阪市域に和汗る流動特性」史泉，65，1987.

あらかじめ指定された上記の論文について討論が かわされた。

野尻論文について，まず論文の趣旨が野尻氏によ り説明もあり, 続いて以下のような質問・意見の交 換が西った。

〉交錯輸送は，外国でもみられるのか。（答）物流 費の中に占める輸送費の割合が下れば，外国でも起 りらる。岁る油種が使用されれば，他の油種が余り だぶつくわけで，ダンピングとなる。700〜 1, 000km の長距離にわたって交錯輸送が括こる。資本系列外 一送る。内航では, 距離增大に上る運賃増大が大し た負担にならない。もっと外に費用のかかるものが 出る。D交錯輸送とは， $\mathrm{A} \rightarrow \mathrm{B}, \mathrm{B} \rightarrow \mathrm{A}$ というもの を指すのか。（答）矢田俊文のいう圈構造を越光た， 沖縄 $\rightarrow$ 北陸, 関東 $\rightarrow$ 北陸といらようなるのを指すと 考光ている。輸送費の増大よりも, 商品自体の価格
差のほうが夫きいような場合に起こり得る。】石油 製品として一括するのではなく，もう少し細かい区 分をしたらえでの分析が必要と考壳られる。（答） 油種別の流動統計は，ほとんど存在しない。系列も 複雑で，それだけでは判定できない。細かい区分の データも公表されていないことが多い。しかし努力 をしてみる必要のある課題である。口この研究は主 飞海運に注目しているが，陸運の上では，油を陸揚 ゲしている港は，ヒンターランドを考光て，量を考 えているのか。（答）陸上のヒンターランドは，タ ンクローリーの場合, わかりにくい。鉄道の場合は 『人文地理』の研究ノートで述べた。タンクローリ 一のヒンターランドは港からドーナ゙ツ状に描けるが, 鉄道より狭小であることは尒想しらる。ただし，鉄 道輸送は減っているので, 瀬戸内 $\rightarrow$ 山陰というょう な，明らかにタンクローリーによる，ヒンタブラン ドを越光た，タンクローリー輸送も見られる。D米 国中西部やソ連のような大陸規模では, 内航海運は 影響がない。そういうところでの物流構造はどのよ らな図式が考光られるか。（答）陸上の場合は, 輸 送費は明確に距離に対応する。和先らく圈構造が見 られよう。ただし, 先進諸国で, 輸送手段が色々選 べる場合には, 複雑で空間的分析はむつかしいであ ろう。DMelamid (1962) は, 日本に挌䑙る原油の 価格は，ペルシャ湾岸なぞの輸出国での建值で決っ ていて, 世界のどこの港へ陸揚げしょうと, 輸入国 での価格には影響しないと述べたが，現在ではどう か。つ和そらく，まだその通りだろうと思う。した がって，陸揚げ地点は大市場の近くへ集中しつつあ るのではないか。D論文の第 5 図によれば,タンク ローリーの輸送距離は $90 \mathrm{~km}$ どまりだが，最長輸 送距離はどらか。（答）大体 $70 \mathrm{~km}$ 以内位のとこ ろがタンクローリーで，といらことになるが，冬に 堺から鳥取までの灯油需要地へ運んでいる例もある。 〉わが国では，パイプラインの可能性はないのか。 （答）室蘭あるいは苫小牧から札幌間といらのは可 能性がある。他の地域は可能性が低い。D内航用の タンカーはどれ位のトン数か。中東からのタンカー が流用されることはないのか。（答）中東用のもの の流用法ない。内航用は, 大体 1,000 トン詰めるか 
ら，その位のサイズとみてよい。D内航用タンカー は，色々な油種に共通して使らことが可能なのか。 （答）重油に関しては，専用船が必要。それ以外の 油種については一隻の船で共通して運べる。〉論文 中での Ullman に対する 批判は適切でない。当時 （Ullmanが言及した時）と，現象が変化している。 U11man 以外飞研究の新しいものがあるはずだ。空 間的なパターンだけでなく，もっ之研究が進んでい るのが現状である。（答）Hay などは是非見なけれ ばならないと思っている。D原油・費用計算をして みた場合, 内地油槽所 $\rightarrow$ 卸売末端までのルートの上 で, 輸送費の占める割合はどれ位か。（答）ガソリ ン1リットルで， 5〜 7 円が高い方，と聞いている。 輸送費よりも広告宣伝費などの方がもっとかかって いるということである。】野菜の輸送コストの場合 でも，信州から東京へ出そうと大阪へ出そうと，そ んなものは関係ない, 売值次第だと農協はいう。こ れでは立地論はメチャクチャになる。輸送コストに 見光ていて，内部にかくされているコスト以外の要 因，たと壳ば，事故の危険性，保険料，道路の淽滞 状況などをも考慮した立地論が必要になるう。また， 輸送費が問題にならないといわれながら，それでむ やはり内航海運といら輸送費の安いものが最も良く 使われている点は見逃してはなるまい。D油種によ って価格が違うであろうし，交錯輸送の行いにくい ものも㐫らう。(答) 内航海運では, 白油の油種に よる運賃差は設けられていない。しかし，油種によ り, 地域的消費量に差があるものが多いので, 帰り 荷のよらなものも存在するよらだ。油種別の調査は なかなか難しい。Dこの研究の将来性について。石 油以外のもの，たとえば他の食料や原料など，他の 輸入品に対する一般化がぞうできるのか。一般化に よって，港や高速道路のプランにもつながるであろ う。（答）石油の輸送量は大きいが，鉱工業製品の 中では特殊な輸送形態であろう。いろいろな物資の 輸送を研究する必要があると思う。他の品目では, 輸送期間の短縮ということの方が，輸送費よりも重 要視される場合も十分あるのではないか。注文がく 杖，すぐに届ける，といらシステムになりつつあ る。現在, トラック輸送の全国的ネットワークの形
成過程を研究しつつあるところである。Dフーバー の説に対して, あてはまらない例を提出し, それは 興味があるが，それが一般化されるかどらか，とい ら検討も必要であろう。

《休 㮩》

石川雄一論文について，まず石川氏より論文の趣 旨説明があり，ついで討論に入った。】地下鉄との 相互乗り入れの乗り継ぎ客は, 私の鉄道からの客は ぞのように取り扱ったか。市営地下鉄のみを取った のか。（答）市営地下鉄のみをとった。D市営地下 鉄による調査は，全流動のどれくらいを捕捉してい るのか。（答）地下鉄内に関しては多少の受け渡し ミスはあららが，100\%回収となっている。D自転 車利用者のデータをのせてないが，ぞう处理したの か。（答）絶対数が少いので省略した。】地下鉄乗 降客によって, 都心域を分類 (定義) しているが, 都心域が既往の研究成果に比べてやや広く出ている。 その原因は何であろらか。（答）従来のものは, 建 物の延べ床面積など，資本関係の指標によっていて， ここでの指標と性格が大きく違うからであるう。今 回の結果では, 都心域は従来のものより, やや西へ 延びている。D地下鉄ネットワークの中で，路線間 の乗り換光の役割はどのように出ているか。因子分 析を施した他の成果では, 各路線ごとに同一パター ンが出てくる。乗り換光による異なったパターンの 混入はどの程度の意味をもつのか。（答）朝のラッ シュなど, 中心部への乗り継ぎの多い御堂筋線の意 味が大きい。】乗り換光の意味が大きくなる場合と いらのは, 大国町駅 (注. 四つ橋線と御堂笳線が交差。 同じホームで乗り換觉可能で，乗り換穴客が非常に 多い駅）のような構造の駅があることと関係するの か。（答）乞ら思う。口市営地下鉄の交通量調查は, 或る一日の結果か。（答）然り。私鉄と同じ日のウ ィークデーに実施している。以前は毎年和こなって いたが，最近は数年に一度ずつである。】帰りの時 間帯は，17時台より18時台の方が混むようだし，2 時間分（17〜19時）とった方がよいのではないか。 （答）やはり17時台が最大となって沏り，17時台を とるのがよいと思う。D朝の 8 時台と夕方の 17 時台, それら以外を一括したのは妥当か。（答）利用した 
統計がそのような区分になっている。つまり, 公表 データでは, 8 時台と17時台と, それ以外の 3 つ しか区分されていない。 $\triangle \mathrm{J} R$ 環状線も市内で完結 しているので，地下鉄と一体のネットワークを成し ていると考光られる。環状線の駅では, その周辺に 大事業所がそれほどあるとは思觉ないのに，私鉄と のクロス駅で人がぞっと乗降するのはなぜか。（答） 私鉄（郊外） $\rightarrow$ 環状線 $\rightarrow$ 私鉄（郊外）という通過の 流れがあるのではないか。】地下鉄が不便なところ では, バスで都心まで行く人も多いのではないか。 また，時間帯によっては，地下鉄とバスとの間で利 用の選択が扣こなわれているのではないか。昼間は ガラガラに空いているバスが，朝は乗客の多い例が ある。（答）大阪市西南部や東淀川区でバス利用率 の高いところがある。しかし，全体として，地下鉄 との間に格差がある。D地下鉄のない地区ではバス の地位は高い。バスについての分析も必要だ。(答) 大阪市の交通量調查ではバスについてはつかめない。 運行回数×定員で出せないものかと思っている。も っとも, パーッントリップ調査では, バスは大阪市 域の場合, 小さい。私鉄の交通量調查と連結した 分析はできないか。（答）パーソントリップのマス ターテープを使光ば，同様な分析は出来るかもしれ ないが，私鉄の調査との連結は難しい。私鉄と大阪 市が，同時にタイアップした調查を実施するとよい が。 $\triangleright 8$ 時台, 17時台, それ以外の時間帯, という 区分は，大都市圈内の流動については妥当であろう。 しかし，それ以外 (昼間) の時間帯についての研究 が，大都市の構造を知るのに役立つであるう。つま り，時間帯を 2 つ分けて，ひとつは，8時台，17 時台といら大都市圈をみると場, 他のひとつは昼間 の都市内をみる立場, といら分析の目的を变光るこ とだ。D以前は, 都心への評価は低くなる傾向があ ったが，別の面がでてきたと思う。最近の都心の土 地ブームは，モータリゼーションによる，これまで の分散指向とはちがった傾向があらわれ，地下鉄が 地価上昇に寄与しているのではなかららか。D都心 がモータリゼーションに対応していることも事実で, 駐車場建設も進んでいる。しかし, 対応の選択肢は 増加するような方向で進んでいるのではないか。駅
勢圏の狭さにもかかわらず，地下鉄駅の乗降客が多 いといらのも，その一つのあらわれかもしれない。 昼間のビジネスマンの地下鉄の短距離利用が多いの も大きく効いているのではないか。】昼間も自動車 利用が多いといらのが, 従来のパーソントリップ調 查での常識だったが，考克直す必要があるかもしれ ない。メアメリカでは, パーソントリップ調査は有 效性について限界があるとされている。D地下鉄に は市電廃止の代替としての意味が大きい。高速道路 のランプウェイと連絡のある場所の地価が上がり, 場所の評価が高まった，土地利用が高度化した，と いらよらな例がみられるが，地下鉄駅に関しては似 たような例は見られるか。（答）事例はあると思う。 ○市電時代と地下鉄時代とでは, 都市構造が変化し ている。市電の停留所数の 3 分の 1 ぐらいに地下鉄 駅が少数化したが, その少数の地下鉄駅の付近へ重 要な機能が集中してきている。現に今では, 市外か ら通勤以外の用事で大阪市内へ来る者にとっては, 環状線と御堂筋線とで大部分の用事は済んでしまう。 ○地下鉄の駅構内とか，同じ名前の地下鉄駅（難波 とか銀座）間で歩かされる距離が非常に長くなって いる。メンタルマップでは同じ地点であるが, 我々 の何々駅というもののあらわす地点の範囲と, 都市 計画を抢こなら者のもつ駅の範囲の通念との間には ズレがある。D地下鉄流動の全流動に対する比率は ぞれ位か。(答) 環状線内では63\%, 都心三区で76 \%である。

〔付記】当日はフェーン現象がみられ，戸外は暑い 南風が吹いたが，会場は冷房が利き，快適であった。 討論も, 前回とは異なり, 大学院のゼミのような精 縝な質疑が交わされ，ぞちらかといえば，クールな 発言が多かった。両氏論文ともは既存公表データを もとにした分布なので, 資料のもつ, 内容の限界性 が感じられたが, 新しい視点からの取り組みに関心 を呼んだ。あとの懇親会は一変して, 賑やかな談笑 の場となった。(参加者15名 司会 須原芙士雄)

\section{文 献 解 題}

Richard C. Jones (ed.): Pattrens of undocu-

mented Migration; Mexico and the United 